\title{
A revision of the types of two Scathophagidae species (Diptera), described by Becker and deposited in the Zoological Institute, St.-Petersburg, Russia
}

\section{Изучение номенклатурных типов двух видов Scathophagidae, описанных Becker и хранящихся в колмекщии Зоологического института, Санкт-Петербург, Россия}

\author{
A.L. Ozerov ${ }^{1}$, M.G. Krivosheina ${ }^{2}$ \\ А.А. Озеров, ${ }^{1}$ М.Г. Кривошеина ${ }^{2}$

\begin{abstract}
${ }^{1}$ Zoological Museum, Moscow Lomonosov State University, Bol'shaya Nikitskaya 6, Moscow 125009 Russia, e-mail: ozerov2455@rambler.ru

'Зоологический музей, Московский государственный университет им. М.В. Ломоносова, Большая Никитская ул., 6, Москва 125009 Россия

${ }^{2}$ A.N. Severtzov Institute of Ecology and Evolution, Russian Academy of Sciences, 119071 Moscow Russia, e-mail: dipteramarina@rambler.ru

${ }^{2}$ Институт проблем экологии и эволюции им. А.Н.Северцова РАН, Ленинский проспект, 33, Москва 119071 Россия
\end{abstract}

KEYWORDS: Diptera, Scathophagidae, Scathophaga, Scathophaga albidohirta, Scathophaga infumata, Zoological Institute, St.-Petersburg, Russia, types, lectotype, revision.

КЛЮЧЕВЫЕ СЛОВА: Diptera, Scathophagidae, Scathophaga, Scathophaga albidohirta, Scathophaga infumata, Зоологический институт, С.-Петербург, Россия, типы, лектотип, ревизия.

ABSTRACT. The types of Scathophaga albidohirta (Becker, 1907) and Scathophaga infumata (Becker, 1907) (Diptera, Scathophagidae) are studied. Lectotype for $S$. albidohirta is designated. Redescriptions are given and illustrations of male terminalia of both species are presented for the first time.

РЕЗЮМЕ. Изучены номенклатурные типы Scathophaga albidohirta (Becker, 1907) и Scathophaga infumata (Becker, 1907) (Diptera, Scathophagidae). Обозначен лектотип для S. albidohirta. Даны переописания и впервые приводятся иллюстрации терминалий самцов для обоих видов.

\section{Introduction}

Both species discussed below were described by Theodor Becker from the materials collected during two expeditions to China organized by Imperial Russian Geographical Society. Detailed reports of the expedition to Central Asia under the direction of V.I. Roborowsky in 1893-1895 and expedition to Mongolia and Kum under the direction of P.K. Kozlov were published by P.K. Kozlov [Kozlov, 1899, 1905].

Taxonomic part

Scathophaga albidohirta (Becker, 1907)

Figs 1-5.
Scatophaga albidohirta Becker, 1907: 254. Lectotype $0^{7}$, «Kurlyk» [CHINA: lake Hurleg Hu $\left(37.28^{\circ} \mathrm{N}, 96.89^{\circ} \mathrm{E}\right)$ ], in ZISP [see designation below].

The species was described from 8 specimens from China; male being described more completely. 7 specimens, 2 males and 5 females, are kept in the collection of the Zoological Institute St.-Petersburg (E. Nartshuk, personal communication). We examined 4 of them: both males and 2 females. Information about the rest specimens was got from E. Nartchuk.

ऽ with label «Курлык, Баингол вост. Цайдамъ. Роб[оровский] Козлов 21.V.[18]95» [Kurlyk, western Baingol, Caidam, 21.V.1895, coll. Roborowsky et Kozlov] corresponds to original description and is labelled and designated herewith as lectotype of Scathophaga albidohirta. Lectotype is pinned, one of middle legs glued to geographical label and without tarsomers 2-4, the other middle leg lost, tibia and tarsi of left hind leg lost, as well as tarsomers 2-4 of right hind leg; abdomen cut and mounted in tube with glycerol on the same pin with the specimen. All the rest specimens of the type seria (syntypes) are labelled as paralectotypes of Scatho-phaga albidohirta. Among them:

+ with the label «р[ека] Орогын Сартын ю[жнее] Наньшаня[,] Гоби[,] Роб[оровский] Козлов 320.V.[18]95» (our study) and 2 क⿱ with labels «оз. Иче - p. Орогын с. Цайдам ц. Гоби РобКозлов 3 VII 95» and «p. Орогын Сыртын ю. Наньшаня Гоби РобКозлов 3-20 VII 95» (communication by E. 

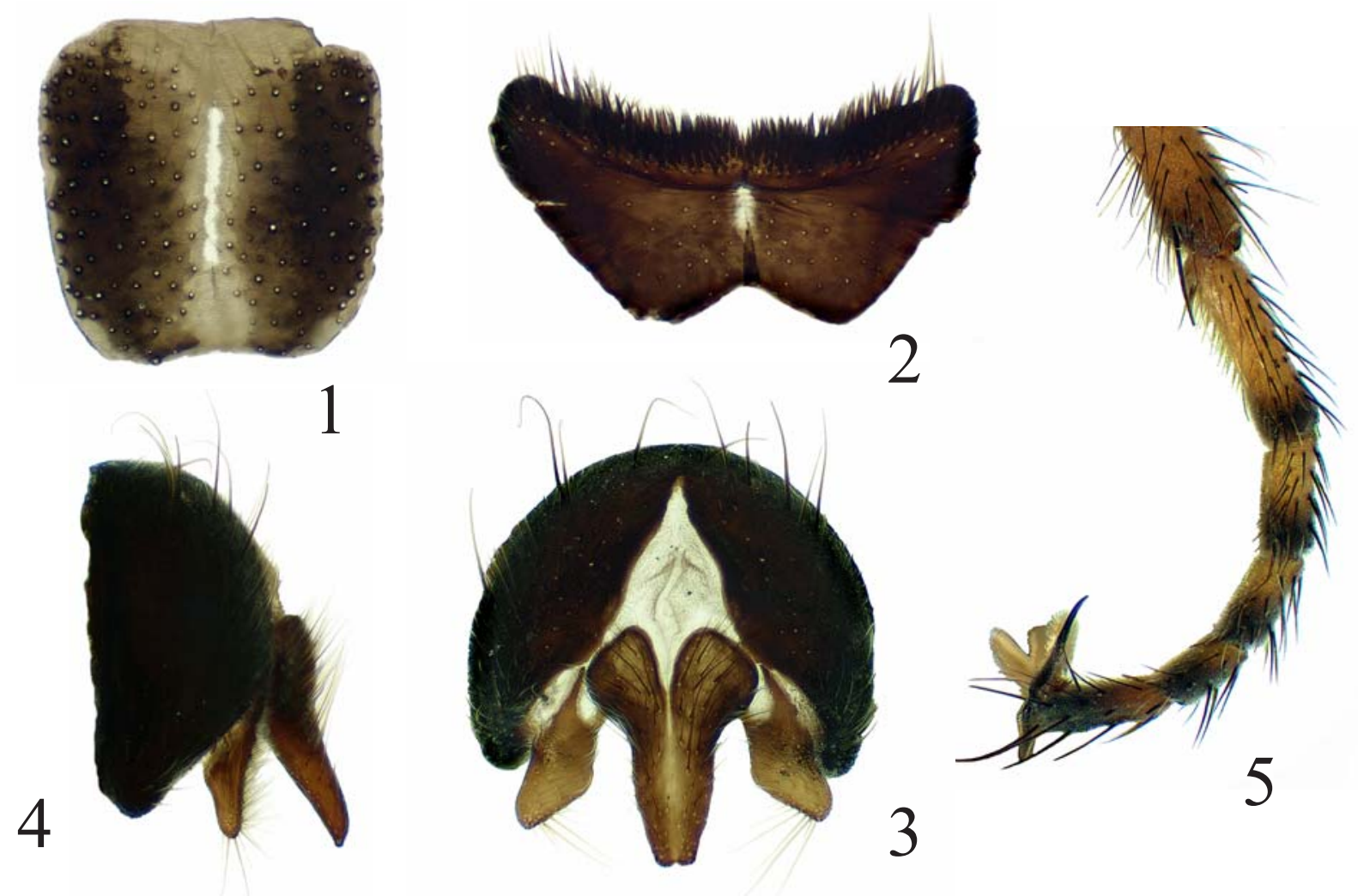

Figs 1-5. Scathophaga albidohirta (Becker), LT O : 1 - sternite 4;2 - sternite 5; 3 - epandrium, cerci and surstyli, dorsal view; 4 - epandrium, cercus and surstylus, lateral view; 5 - fore tarsus.

Pис. 1-5. Scathophaga albidohirta (Becker), LT O’: 1 - стернит 4; 2 - стернит 5; 3 - эпандрий, церки и сурстили, сверху; 4 эпандрий, церк и сурстиль, сбоку; 5 - лапка передней ноги.

Nartchuk) have dark rings on tarsomers and belong to S. albidohirta (see redescription below).

$\sigma^{7}$ with the label as in holotype, was determined by us as Scathophaga mihalyii (Šifner, 1975).

q with the label «Кара Тюбе, на зап[ад]. от Хами, Гоби. Роб[оровский] Козлов 5.IX.[18]95» and + with the label «p. Бомын (Ичегын) св. Цайдам Гоби РобКозлов VI 95» have completely yellow tarsi (without dark rings) and surely don't belong to S. albidohir$t a$. However it is impossible to determine them to species from females and each of them were signed as Scathophaga sp.

The eighth syntype (labelled as paralectotype of $S$. albidohirta also) is kept now in the collection of the Museum für Naturkunde der Humboldt-Universität, Berlin. It is $\sigma^{7}$ with dark rings on tarsomers and it belongs to $S$. albidohirta. It is labelled «оз. Иче - p. Орогын с. Цайдам ц. Гоби РобКозлов 3 VII 95» and two labels handwritten by Th. Becker: «Gobi, Asien VII. 51896», «albidihirta Beck.» (personal communication from Dr. J. Ziegler).

REDESCRIPTION. Length of body $6.1-6.7 \mathrm{~mm}$. Length of wing $5.8-5.9 \mathrm{~mm}$.

Male. Head. Frons matt, yellow in lower part and black in upper part. Eye orbit, ocellar triangle and postcranium black with whitish microtrichia. Face and gena pale yellow with whitish microtrichia. Chaetotaxy: 3-4 or, 3-5 fr, 1 oc, poc absent, 1 ivt, 1 ovt, with a row of 4-5 setae behind eye and below ovt; postcranium with dense whitish hairs. 1 pair of strong vibrissae and 2-4 pairs of short subvibrissae. Antenna black. Postpedicel with slightly acute dorsoapical corner, approximately 2 times as long as wide; arista brownish to blackish, bare. Clypeus and prementum black. Palpus filiform, without long apical seta, yellow with darkened apex.

Thorax black, greyish microtrichose. Scutum chaetotaxy: pprn if present, not differing from hairs on postpronotal lobe, $2 \mathrm{npl}, 1+2 \mathrm{spal},(0-1)+(1-2) \mathrm{ial}, 2$ pal, 2+3 dc. Proepisternum, proepimeron, anepisternum and katepisternum with pale hairs. Anepimeron bare. Anepisternum with 2-3 long setae near posterior margin. Katepisternum with 1 seta in posterodorsal corner. Scutellum with 2 pairs of strong setae and with hairs laterally.

Legs. Femora of all legs greyish microtrichose, black in basal 4/5 and yellow apically. Tibiae and tarsi of all legs yellow; each tarsomere at least of foreleg with blackish ring apically (Fig. 5). Forefemur with pale hairs, without conspicuous setae. Foretibia without conspicuous setae. Midtibia with $1 p d$ and $1 \mathrm{ad}$ in apical 

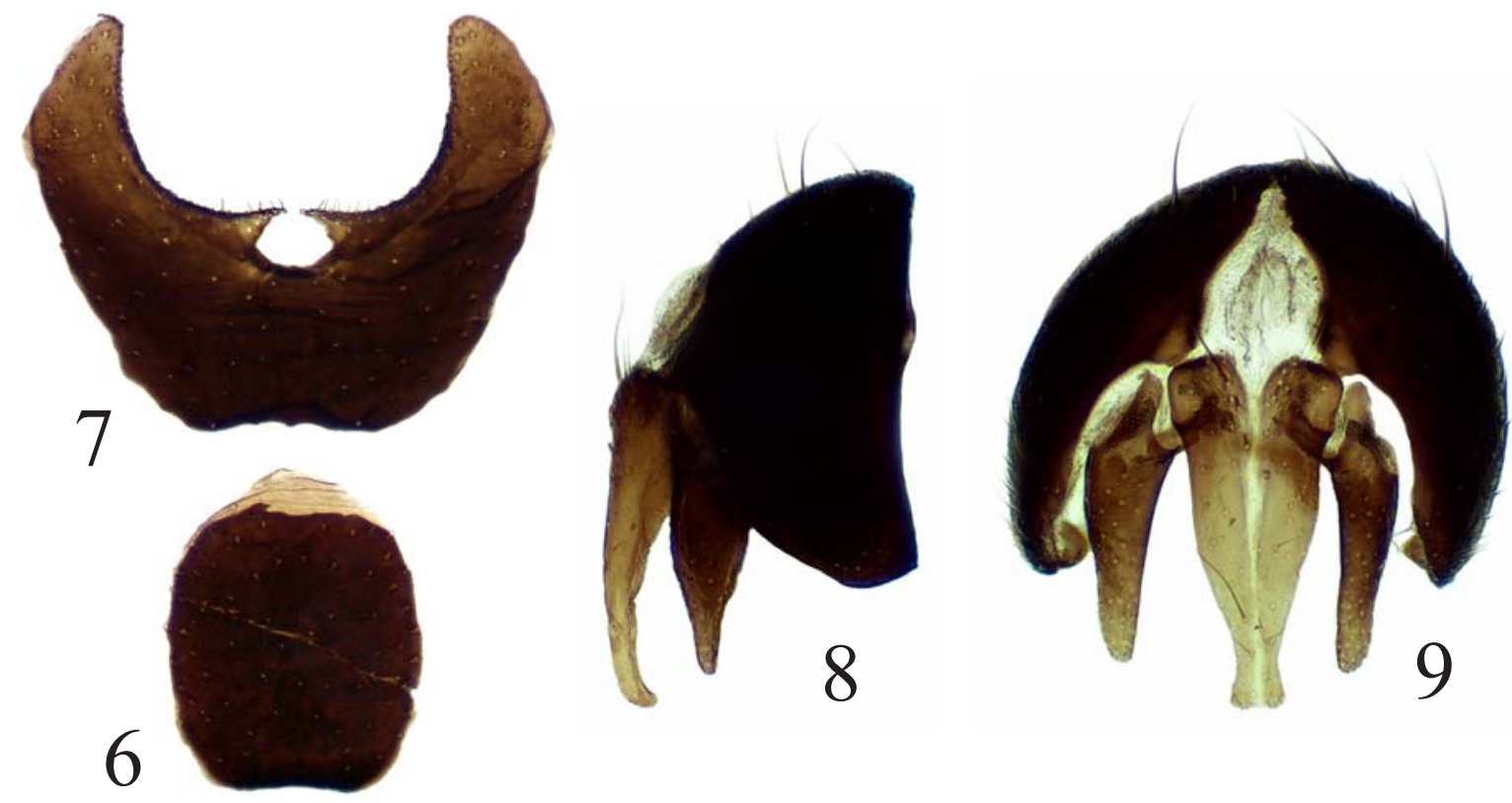

Figs 6-9. Scathophaga infumatum (Becker), HT $0^{7}: 6$ - sternite 4; 7 - sternite 5; 8 - epandrium, cercus and surstylus, dorsal view; 9 - epandrium, cercus and surstylus, lateral view.

Рис. 6-9. Scathophaga infumatum (Becker), НТ O': 6 - стернит 4; 7 - стернит 5; 8 - эпандрий, церки и сурстили, сверху; 9 эпандрий, церк и сурстиль, сбоку.

quarter, and with ring of apical setae. Hindtibia with 1-2 pd, 2 ad and apicals $a v$ and $a d$.

Wing brownish with blackish veins. $\mathrm{R}_{1}$ bare. Calypteres, including margins, yellowish. Halter yellow.

Abdomen black with grey microtrichia and whitish hairs. Tergites 2-6 each with row of marginal setae. Sternites 4 and 5 as in Figs 1, 2. Cerci and surstyli as in Figs 3, 4.

Female. Frons and palpus completely yellow. Femora black in middle part and yellow near base and near apex. Each tarsomere of all legs with black ring apically. Forefemora without conspicuous setae. Midfemur with 1 thin $p$ apically. Hindfemur with row of thin $a d$. Foretibia with $2 a d, 2-3$ thin $p d, 2$ thin $p$ in apical half. Midtibia with 1-2 $p$ in apical half, with $1 p d$ and $1 \mathrm{ad}$ in apical quarter, with 1 preapical $d$, and with ring of apical setae. Hindtibia with $2 p d$ and $2 a d$, with 1 preapical $d$, and with ring of apical setae.

Identity. This is a good species of Scathophaga.

\section{Scathophaga infumata (Becker, 1907)}

$$
\text { Figs 6-9. }
$$

Coniosternum infumatum Becker, 1907: 256. Holotype $\sigma^{\rtimes}$, «Sogon-gomba» [CHINA: the upper reaches of the Yangtze, $\sim 33.6^{\circ} \mathrm{N}$, $96.4^{\circ} \mathrm{E}$.], in ZISP.

The species was described from single male with geographic label «Согон-гомба вер[ховье] Голубой Козловъ кон[ец] VII.[19]00» and 3 labels handwritten by Th. Becker: «Tibet, Kozl.[ov] VII. [19]00», «infumatum Beck.», «5», is kept in the collection of the Zoological Institute RAS, St.-Petersburg.
The holotype is pinned, in very good condition, left wing is torn slightly, abdomen cut and mounted in tube in glycerol on the same pin with the specimen. The map in the report by P.K. Kozlov [1905: map list 4) allows us to determine approximate geographic coordinates of "Sogon-Gomba" — $33.6^{\circ} \mathrm{N}, 96.4^{\circ} \mathrm{E}$.

REDESCRIPTION. Length of body $4.2 \mathrm{~mm}$. Length of wing $3.6 \mathrm{~mm}$.

Head. Frons matt, black, with wide yellow stripe near lunula. Eye orbit, ocellar triangle and postcranium black with whitish microtrichia. Face blackish with greyish microtrichia. Parafacial and gena pale yellow with whitish microtrichia. Chaetotaxy: 3 or, 2-3 fr, 1 $o c, 1$ poc, $1 \mathrm{ivt,} 1$ ovt; postcranium with dense whitish hairs. 1 pair of strong vibrissae. Antenna black. Postpedicel rounded apically, approximately 2 times as long as wide; arista black, bare. Clypeus and prementum black. Palpus filiform, without long apical seta, yellow.

Thorax black, greyish miscrotrichose. Scutum chaetotaxy: pprn absent, $2 \mathrm{npl}, 1+2 \mathrm{spal}, 0+1 \mathrm{ial}, 2 \mathrm{pal}$, $2+3 d c$. Proepisternum, proepimeron, anepisternum and katepisternum with pale hairs. Anepimeron bare. Anepisternum with 2 long setae near posterior margin. Katepisternum with 1 seta in posterodorsal corner. Scutellum with 2 pairs of strong setae, dorsally bare.

Legs black. Femora with pale hairs, without conspicuous setae; fore and mid femora without conspicuous setae, hindfemur with row of thin $a d$. Foretibia with $2 d$ and brush of dense short golden hairs on $p v$ surface. Midtibia with $1 p d$ and 1 ad near middle, and with ring of apical setae. Hindtibia with $1-2 \mathrm{pd}, 1 \mathrm{ad}$, 
with 1 preapical $d$, with apical $a v$ and $a d$ and brush of dense short golden hairs on $p v$ surface in apical half.

Wing brownish with blackish veins. $\mathrm{R}_{1}$ bare. Calypteres, including margins, and halter yellow.

Abdomen black with grey microtrichia and whitish hairs. Sternites 4 and 5 as in Figs 6, 7. Cerci and surstyli as in Figs 8, 9.

Identity. This is a good species of the genus Scathophaga.

ACKNOWLEDGMENTS. We wish to thank Emilia Nartchuk (St.-Petersburg) and Joachim Ziegler (Berlin) for the assistance in getting the type materials and the information about some type-specimens.

\section{References}

Becker T. 1907. Zur Kenntniss der Dipteren von Central-Asien. I. Cyclorrhapha schizophora holometopa und Orthorrhapha brachycera // Annuaire du Musée Zoologique de l'Académie Impériale des Sciences de St.-Pétersbourg. T.12. P.253-317.

Kozlov P.K. 1899. [Report of the assistant of the Head of expedition P.K. Kozlov, member of Imperial Russian Geographical Society. Proceedings of Expedition of the Imperial Russian Geographical Society to Central Asia in 1893-1895 under the direction of V.I. Roborowsky. Part 2. St.-Petersbourg. 296 pp.] [in Russian].

Kozlov P.K. 1905. [Mongolia and Kam. Proceeding of Expedition of the Imperial Russian Geographical Society in 1899-1901 under the direction of P.Ê. Kozlov]. Vol.1. 256 pp. [in Russian]. 